\title{
The Development of a Behavior Patterns Rating Scale for Preservice Teachers
}

\author{
Nihat Caliskan ${ }^{1}$, Okan Kuzu² \& Yasemin Kuzu ${ }^{3}$ \\ ${ }^{1}$ Curriculum and Instruction, Ahi Evran University, Kirsehir, Turkey \\ ${ }^{2}$ Elementary Mathematics Education, Ahi Evran University, Kirsehir, Turkey \\ ${ }^{3}$ Measurement and Evaluation in Education, Hacettepe University, Ankara, Turkey \\ Correspondence: Okan Kuzu, Elementary Mathematics Education, Department of Elementary Education, Ahi \\ Evran University, Kirsehir, Turkey. Tel: 90-386-280-5197. E-mail: okan.kuzu@ahievran.edu.tr
}

Received: September 18, 2016

Accepted: October 21, 2016 Online Published: November 14, 2016

doi:10.5539/jel.v6n1p130

URL: http://dx.doi.org/10.5539/jel.v6n1p130

The work was supported by Ahi Evran University Scientific Research Projects Coordination Unit. Project Number: EGT.A3.16.011.

\begin{abstract}
The purpose of this study was to develop a rating scale that can be used to evaluate behavior patterns of the organization people pattern of preservice teachers (PSTs). By reviewing the related literature on people patterns, a preliminary scale of 38 items with a five-points likert type was prepared. The number of items was reduced to 29 after obtaining expert opinions and was administered to 620 PSTs. As the results of the exploratory and confirmatory factor analysis, unlike two factors: structurist and free spirits behavior patterns, in the theory, we obtained the final scale of 15 items consisting of three factors: planners, solution-oriented and prescriptive behavior patterns. The related Cronbach Alpha value was found to be .830 for all the items. We identified that behavior patterns rating scale of the organization people pattern can be confidently applied to evaluate behavior patterns. Moreover, in this study, we obtained a contradiction between practice and theory. Thus, we provided a new idea related to behavior patterns of the organization people pattern.
\end{abstract}

Keywords: behavior patterns, organization people pattern, preservice teachers, rating scale

\section{Introduction}

"Education is the aggregate of all the processes by which a person develops his abilities, attitudes and other forms of behavior, which may help to attain social competence and optimum individual development" (Srinivasan \& Ambedkar, 2015, p. 66). The main purpose of educational systems is to train qualified individuals who respect to human rights and responsible to society, as well as to ensure an effective educational process (Turkish Ministry of Education, 1973). Teachers, who play a vital role in education systems, are known as role-models for providing discipline and preparing students to the life by transferring information. Teachers help students to develope a sense of social responsibility, as well as practical skills such as communication, analytical and intellectual thinking and problem-solving. In addition, they explain how to apply knowledge and skills in real-world settings.

Teachers, who have important roles on the success of students, do the teaching profession, which is known as a profession of the professions, meticulously and by sacrificing from their time. The teaching profession is a key profession in the cognitive and psychomotor learning process of the other professions (Türer, 2009). The teaching profession is an occupational area that related to the social, cultural, economic, scientific and technological dimensions of education and requires professional qualifications and subject-matter expert knowledge and skills in such areas (Sisman \& Acat, 2003). Teachers constitute a significant part of the problems associated with education systems and so it is necessary for them to have professional qualifications. These professional qualifications of teachers, depends on general culture, subject knowledge, teaching profession knowledge, and skills. In addition, teachers' one of the main roles is to enable socializing and culture transfer, and to accomplish this role they have to know cultural features of the society where they live (Erden, 1998). Besides, teachers' professional qualifications, and their personality characteristics are also important. Teachers 
should have desired personality characteristics if they want to be a role-models to their students (Yazic1, 2006). As stated by Yazıcı (2006), if teachers are not good role-models and do not have these characteristics, they lead to loss of available student qualifications. Moreover, teachers' negative personality characteristics, also lead to students being completely distinct from lessons and school and fail in their academic life (Erden, 1998). Therefore, it is necessary to carefully evaluate whether teaching profession is appropriate for the personalities of PSTs. If teaching profession is appropriate for PSTs, their qualifications for teaching profession will be better.

In 1910, the first study related to the teaching profession and personality characteristics was done by Ruediger and Strayer who examine characteristics of successful teachers (Yaakub, 1990). Although, there are some agreed teacher personality characteristics (warm, accessible, humble, enthusiastic and caring etc.) that educators in the field designated, the main problem is whether all of the teachers and PSTs have these characteristics, or not. Hence, at this point "People Patterns" become important (Staddon, 2016; O'Connor \& Seymour, 2011).

Woodsmall and Woodsmall (2003) state that all human beings are creatures of habit, and these habits lead to consistent patterns of behaviour. These patterns are called "People Patterns". People patterns can be utilized to enhance communication. Moreover, for effective communication, Woodsmall and Woodsmall (2003) state that we need to focus on our outcome, observe our patterns, vary our communication until we get the response that we want. In addition, we need to continually verify to make sure that we are succesful. People Patterns assert that modelling approach has to be done for choice of profession or employee. According to this approach, common characteristics of the most successful individuals working in the profession is determined, and so a typology is created. It is referred to this typology when choosing the employees or professional counselling (Woodsmall \& Woodsmall, 2003). Moreover, as stated by them, People Pattern Power framework help us see the flow of ones process for seeing sensing the information in world, than sorting it out by thinking and deciding what we will do with that information, than feeling our motivation for it and lastly organizining activities to get some results.

According to Woodsmall M. and Woodsmall W. (2003), People Pattern Power consist of nine patterns: change, primary interest, information, evaluation, decision, motivation, motive, activity and organization. Each pattern has specific feature, and a test is used to determine the pattern.

"Change Pattern" tells us what is the dominant way the person perceives change in the world and also how they grow their knowledge and how they will cope with change. According to individual perceptions filter, this pattern are examined in four groups: Sameness, Qualified Sameness, Qualified Difference and Difference. This pattern's test states three coins lined up with two heads up and one tail down. Moreover, Change pattern's power question is "What is the relationship among these coins?".

Other pattern is "Primary Interest Pattern", and it has mojor impact on our relationships. According to interest, this pattern are examined in five groups: People (Who), Activity (How, When); Things (What), Place (Where) and Information (all and Why). This pattern's test states, "In some conversations we tend to be fully engaged, but ohter we seem to be looking for fast escape. Why do we try to escape?" In addition, its test's power question is "How was your day yesterday? If you would like to know abaout my day what would interest you the most?"

For "Information Pattern", quantity is defined by how much we need to know in order to build our knowledge. Depending on the answer to the question, individuals in this pattern are examined in two groups: Tangible and Intangible. Moreover, according to Information Pattern Test, how much (quantity) and what (quality+context) we need to get in order to build our knowledge, and its power question is "How much do you want to know? Do you need specific details of big picture? Do you need proof?"

"Evaluation Pattern", one of the nine patterns, states that some people base their decisions on internal criteria while others base their decisions on external criteria. Hence, depending on the source influenced when deciding, this pattern consists of two groups: Internal criteria and External criteria. This pattern's test states "How do we decide what is right for us?" and its power question is "How do you know that what you are doing or propose to do is right? How do you know you have done a good job?"

Other pattern is "Decision Pattern", and as stated by this pattern, we usually think that people do decisions based on make sense, but the truth is $95 \%$ of people decide differently. Individuals in this pattern are examined in four groups: Picture, Sound, Feeling, Logic. Moreover, this pattern's test states how do we decide from multiple options. Its power questions are "What was the last time you both something for yourself? How did you decided to buy this thing. What was the last time you had to decide about something and what was your thinking process?" 
For "Motivation Pattern", every competitive organization should be mainly focused on results. Its test states what is it we want or do not want in life in order to motive ourselves in the boring periods of life. In addition, in this pattern, motives are found in two groups: Inside and Outside. Its power question is "What do you want in... (carrier, job, relationship)? How do you motivate yourself to get out the bed in the morning?"

"Motives Pattern's" goal is to winning, popularity and success. Hence, individuals in this pattern are examined in three groups: Power, Affiliation and Achivement.

Other pattern is "Activity Pattern", and in this pattern, people usually need two distinct things to do something. These are either options or procedures.

The last pattern is "Organization Pattern", and in this study, we will research about this pattern. According to this pattern, people differ in the way they organize their time and space. For this pattern, power questions is "Are they always on time or early or habitually late?". According to Woodsmall W. and Woodsmall M. (2003), individuals in the organization people pattern, which is one of nine patterns, are examined in two groups: "Structurist" and "Free spirits" behavior patterns. Structurists are people who lead very organized lives. They enjoy tidiness, being programmed and certainty in their lives. The individuals with structurist behavior patterns like to plan things in advance because they need some type of structure to guide them in their lives. They have a sense of past, present and future. Structurists also like to organize their space and they tend to be neat and orderly. They tend to plan their works in particular orders and apply the plan they choose on time. They support to comply laws and ethics rules. The individuals who are aware of the time, have decisive and punctual attitudes. On the contrary, the individuals with free spirits behavior patterns like sudden decisions, possibilities and improvisations. They prefer to live their lives spontaneously, as the wind blows, so to speak. They live as they want. They focus on the present moment. They detest structure and avoid planning ahead because it interferes with their unstructured nature. They don't mind piles and untidy spaces around them. Hence, we can say that they have negative attributes such as indecisive and disorganized. Then, Woodsmall W. and Woodsmall M. (2003) claim the Table 1 for structurist and free spirits.

Table 1. Reliable indicators according to Woodsmall W. and Woodsmall M. (2003)

\begin{tabular}{ll}
\hline Structurist & Free spirits \\
\hline Life is organized & Life is spontaneous \\
On time and early & Disorganized \\
Aware of the time & Habitually late \\
Decisive & Lose track of time \\
& Indecisive \\
\hline
\end{tabular}

In this study, we prepared the preliminary scale of 38 items with a five-points likert type by reviewing the related literature on people patterns. In addition, we used the Woodsmall and Woodsmall's ideas about the structurist and free spirits. Statistical analysis have done for the individuals with behavior patterns of the organization people pattern, and free spirits items excluded because they decreased reliabilitiy. As a result of the factor analysis, it has been observed that their typologicals were gathered around "Planners", "Solution-oriented" and "Prescriptive" behaviors. Therefore, our result contradicts with Woodsmall W. and Woodsmall M.'s (2003) theoretical analysis. Woodsmall W. and Woodsmall M.'s idea related to behavior patterns of the organization people pattern is a theoric analysis. We observed that the results from their theoretical analysis and our scientific data contradict. Thus, we claim that the individuals with behavior patterns of the organization people pattern have "Planners", "Solution-oriented" and "Prescriptive" typologicals.

Today, the choice of the teaching profession is a significant problem to be focused. Personality characteristics of PSTs become an important factor in their decision for choosing this profession. In this study, we suggest that it is important to develope a new likert-type rating scale in order to evaluate PSTs in terms of the "Organization People Pattern". The individuals in the organization people pattern have been examined by Woodsmall W. and Woodsmall M. (2003) in two groups: structurist and free spirits behavior patterns. However, we observed that with the use of new scale three such gruops: planners, solution-oriented and prescriptive, emerge. Thus, we provide a new idea related to behavior patterns of the organization people pattern. 


\section{Method}

\subsection{Design}

This study was designed to be a quantitative research and descriptive data are used to identify PSTs' behavior patterns. According to Büyüköztürk et al. (2009), descriptive method is the most common research in the education. We developed in which the original language was Turkish has been developed to evaluate the behavior patterns of the organization people pattern of the PSTs in the description process. Moreover, the scale was translated to English by experts in order to be understood by the other researchers (see Appendix for original scale).

\subsection{Data Collection and Analysis}

By reviewing the related literature, a preliminary scale of 38 items with a five-points likert type was prepared by the authors. After receiving, expert opinions, the number of items was reduced to 29. Each item included "never agree", "agree", "undecided", "agree", "completely agree" as options. The study included 620 PSTs in a Faculty of Education at a University in the central Turkey. The data were analyzed using SPSS 23 (Statistical Package for the Social Sciences 23) programme, and after the crosstab, the data of 612 PSTs have been taken into account. Item-total correlation and exploratory factor analysis were conducted to assess the construct validity of the scale. Tavşanc1 (2014) advised that item-total correlation has to be .30 or higher for the items in the scale. Furthermore, Greca et al. (1998) excluded items with load of the factor less than .30; Hwang and Henry (1990), Tsai and Chai (2005) excluded items with load of the factor less than .40; Huang (2005) excluded items with load of the factor less than .50 in their study. Büyüköztürk (2007) expressed that factor load value has to be .45 or higher. Moreover, the difference between the load of factor in all factor for each item in the scale has to be at least .10 (Bütüner \& Gür, 2007; Yavuz, 2005). In this study, we excluded items with load of the factor less than .45, and excluded items with item-total correlation less than .30. In addition, we excluded items whose difference between the load value in the other factors less than .10. The reliability of the scale was examined with the internal consistency method, and the Cronbach Alpha internal coefficient was computed. As a result of the analysis, the final scale, consisting of 15 items with five-points likert type was obtained. Confirmatory factor analysis was conducted using LISREL 9.2 (Linear Structural Relations 9.2) package programme.

\section{Findings}

A preliminary scale of 38 items with a five-point likert-type was prepared by the authors reviewing the related literature. By expert opinions, the number of itmes was reduced to 29 (see Table 2).

Table 2. The items of preliminary scale of the behavior patterns evaluation scale of the organization people pattern

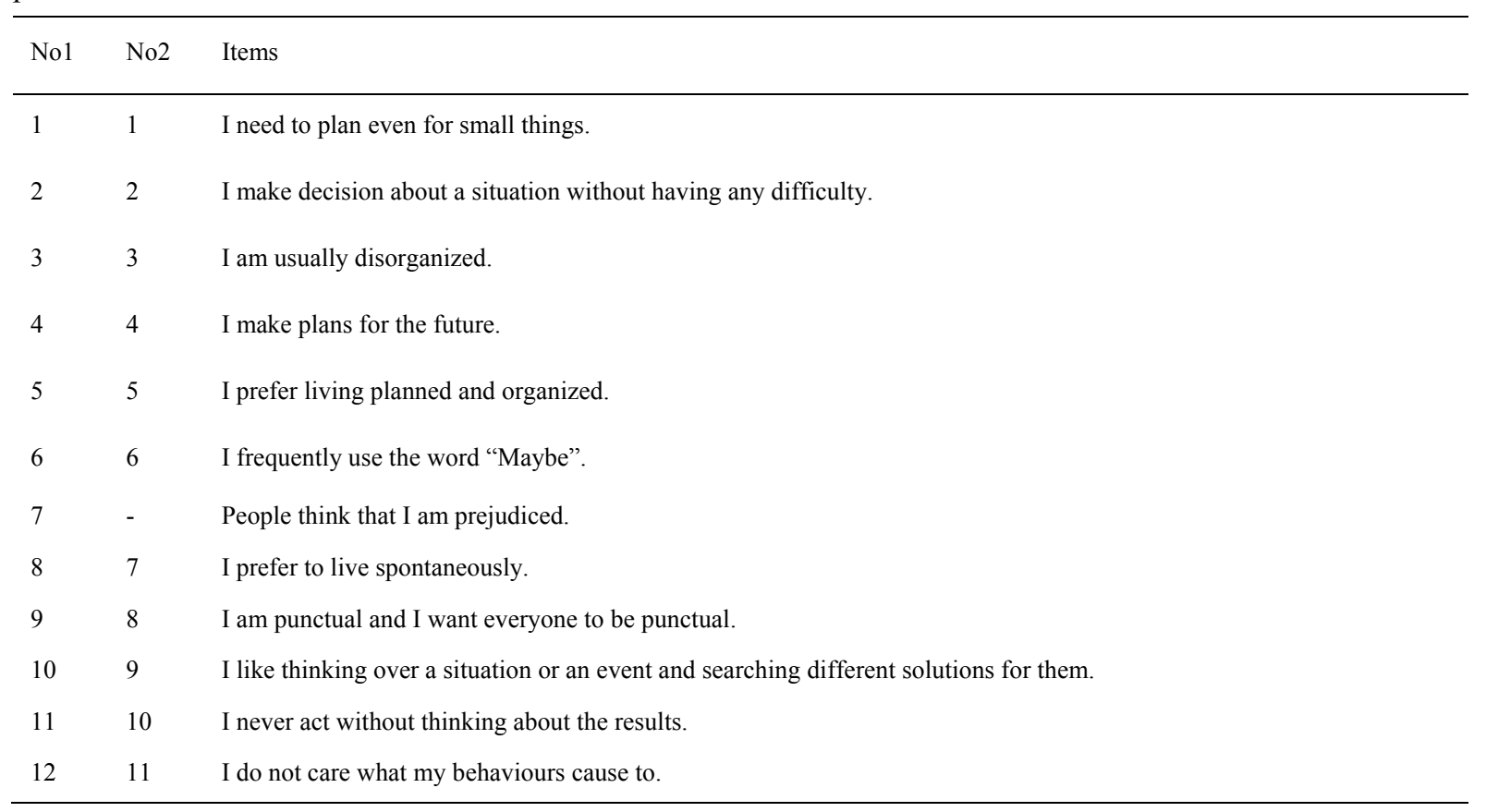




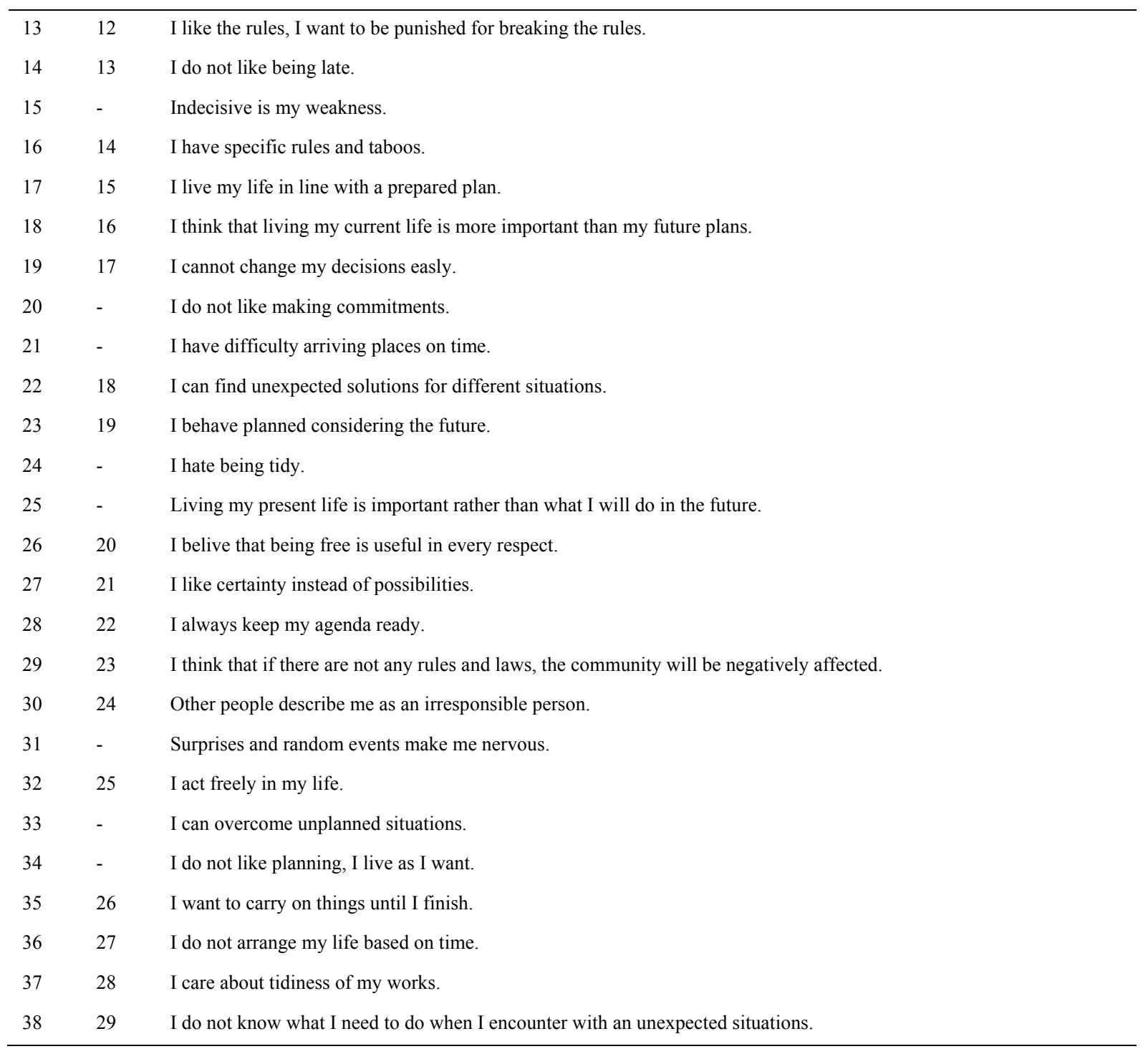

No. 1: The item numbers of preliminary scale with 38 items.

No. 2: The item numbers of preliminary scale witth 29 items.

In the final analysis of 29 items, first, the item-total correlation was examined in order to decide the number of items in the scale. The items: 2, 3, 6, 7, 11, 13, 16, 20, 24, 25, 27, 29 were excluded because their item-total correlations were less than .30 . In addition, items 21 and 23 items were excluded because they decrease the Cronbach Alpha reliability coefficient even though their item-total correlations were above .30 .

Next, an exploratory factor analysis was carried out to test the construct validity of the scale. To do that, we examined whether the data were appropriate to conduct the exploratory factor analysis. Therefore, we checked whether the size of the sampling was adequate with the Kaiser-Meyer-Olkin (KMO) test. In this study, KMO coefficient was found to be .875 (see Table 3).

Table 3. Kaiser-Meyer-Olkin (KMO) and Bartlett's test of sphericity

\begin{tabular}{lll}
\hline Kaiser-Meyer Olkin Measure of Sampling Adequacy & & .875 \\
\hline & Approx Chi-Square & 2297.287 \\
Bartlett's Test of Sphericity & df & 105 \\
& $\rho$ & .000 \\
\hline
\end{tabular}


Kaiser (1970) states that KMO coefficient is between 0 and 1 . According to Kaiser, the closer to 1 the sampling is more appropriate to the factor analysis. As stated by the experts, if the alpha coefficient is between .80 and 1 , the scale is very reliable (as cited in Tavşanc1l, 2014). Besides, in factor analysis, the distribution in the setting is expected to be normal, which is tested by Bartlett test. In this study, meaningfulness value of Bartlett test was found to be significant $(p<.01)$. According to the results of KMO and Bartlett test, we observed that our data was appropriate for the factor analysis. Total variant rate of the scale was computed as $48.932 \%$ (see Table 4 ). As stated by Tavşancil (2014), the variant rate that is between $40 \%$ and $60 \%$ is sufficient for analysis in the social sciences.

Table 4. Total variance explained

\begin{tabular}{|c|c|c|c|c|c|c|c|c|c|}
\hline \multirow{2}{*}{ Component } & \multicolumn{3}{|c|}{ Initial Eigenvalues } & \multicolumn{3}{|c|}{ Extraction Sums of Squared Loadings } & \multicolumn{3}{|c|}{ Rotation Sums of Squared Loadings } \\
\hline & Total & $\begin{array}{l}\text { Var. } \\
\%\end{array}$ & $\begin{array}{l}\text { Cum. } \\
\%\end{array}$ & Total & $\begin{array}{l}\text { Var. } \\
\%\end{array}$ & $\begin{array}{l}\text { Cum. } \\
\%\end{array}$ & Total & $\begin{array}{l}\text { Var. } \\
\%\end{array}$ & $\begin{array}{l}\text { Cum. } \\
\%\end{array}$ \\
\hline 1 & 4,671 & 31,141 & 31,141 & 4,671 & 31,141 & 31,141 & 3,398 & 22,655 & 22,655 \\
\hline 2 & 1,467 & 9,779 & 40,921 & 1,467 & 9,779 & 40,921 & 2,031 & 13,541 & 36,196 \\
\hline 3 & 1,202 & 8,012 & 48,932 & 1,202 & 8,012 & 48,932 & 1,910 & 12,736 & 48,932 \\
\hline 4 & ,928 & 6,189 & 55,121 & & & & & & \\
\hline 5 &, 872 & 5,813 & 60,934 & & & & & & \\
\hline 6 &, 809 & 5,395 & 66,329 & & & & & & \\
\hline 7 & ,788 & 5,256 & 71,585 & & & & & & \\
\hline 8 & 684 & 4,560 & 76,144 & & & & & & \\
\hline 9 & 662 & 4,414 & 80,558 & & & & & & \\
\hline 10 & ,618 & 4,123 & 84,681 & & & & & & \\
\hline 11 &, 569 & 3,793 & 88,474 & & & & & & \\
\hline 12 &, 534 & 3,561 & 92,035 & & & & & & \\
\hline 13 & 453 & 3,021 & 95,056 & & & & & & \\
\hline 14 &, 394 & 2,628 & 97,684 & & & & & & \\
\hline 15 & 347 & 2,316 & 100,000 & & & & & & \\
\hline
\end{tabular}

Varimax technique was also applied because it was expected that our scale has many factors (Kline, 1994; Rennie, 1997; Stapleton, 1997; Stevens, 1996). After conducting the factor analysis with the Varimax technique for 15 items, the items were gathered under three factors. The factor load value of each item was found to be high in the only one factor. Moreover, the factor load values were between .565 and .782 for the first factor; .550 and .743 for the second factor; and 471 and .720 for the third factor (see Table 5).

Table 5. Rotated component matrix

\begin{tabular}{llcc}
\hline & \multicolumn{2}{c}{ Factors } \\
\cline { 2 - 3 } Items & $\mathbf{1}$ & $\mathbf{2}$ & $\mathbf{3}$ \\
\hline Item 5 & .782 & \\
Item 19 & .698 & \\
Item 28 & .680 & \\
Item 4 & .660 & \\
Item 1 & .659 & \\
\hline
\end{tabular}




\begin{tabular}{llll}
\hline Item 22 & .579 & & \\
Item 15 & .565 & .743 & \\
Item 9 & & .734 & \\
Item 18 & .593 & \\
Item 10 & .550 & \\
Item 26 & & .720 \\
Item 17 & & .680 \\
Item 14 & & .548 \\
Item 8 & & .471 \\
Item 12 & & \\
\hline
\end{tabular}

In this study, we called the first factor as "Planner" behavior pattern for items: 1, 4, 5, 15, 19, 22, 28. We called the second factor as "Solution-oriented" behavior pattern for items: 9, 10, 18, 26. The third and last factor "Prescriptive" behavior pattern for items: 8, 12, 14, 17 (see Table 6).

Table 6 . The factor distribution of the items in the preliminary scale

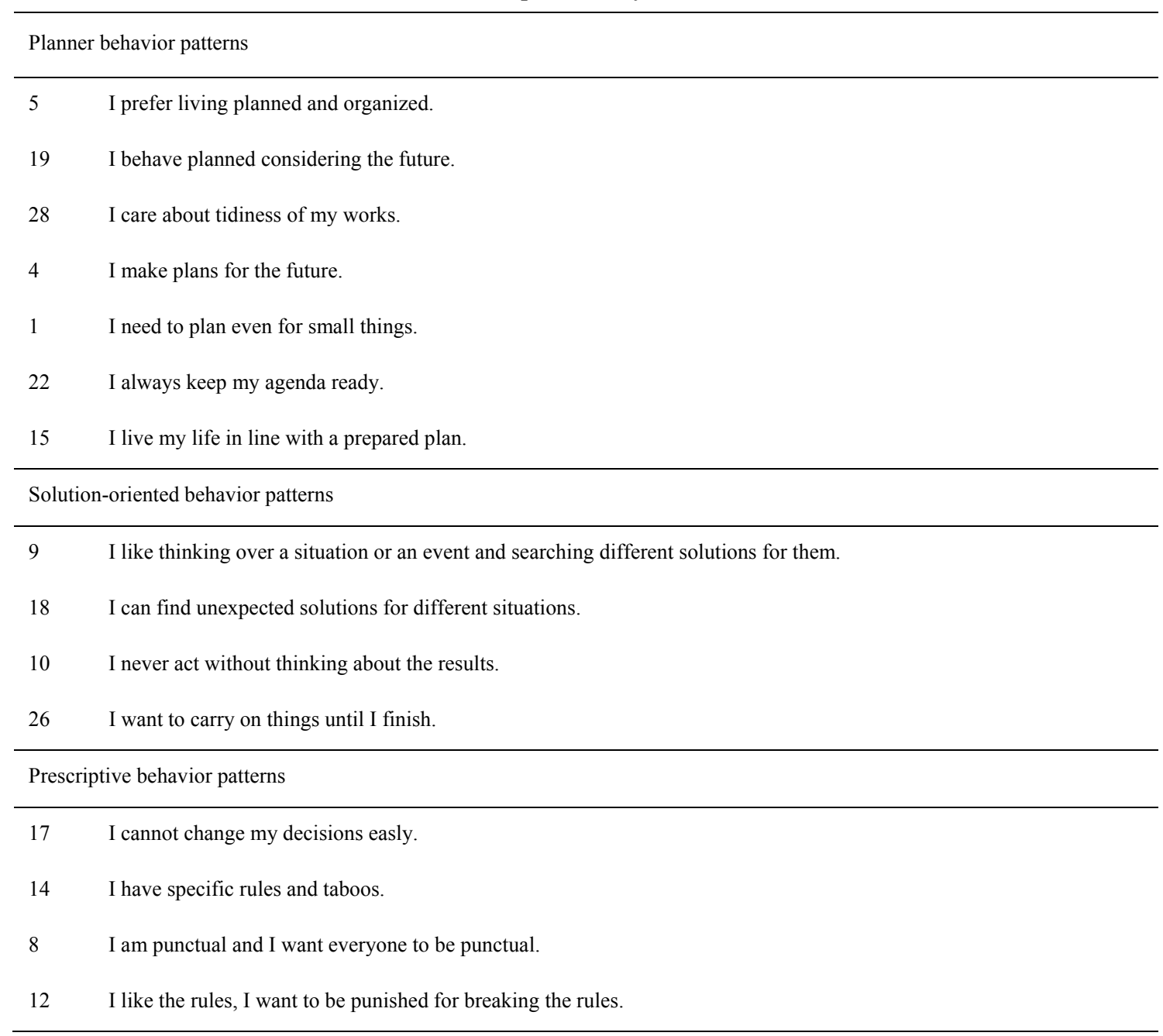

In Figure 1, the line graph which is the related to the organization people pattern rating scale is given. From eigenvalues of this line graph, it is seen that the scale has three factors. 


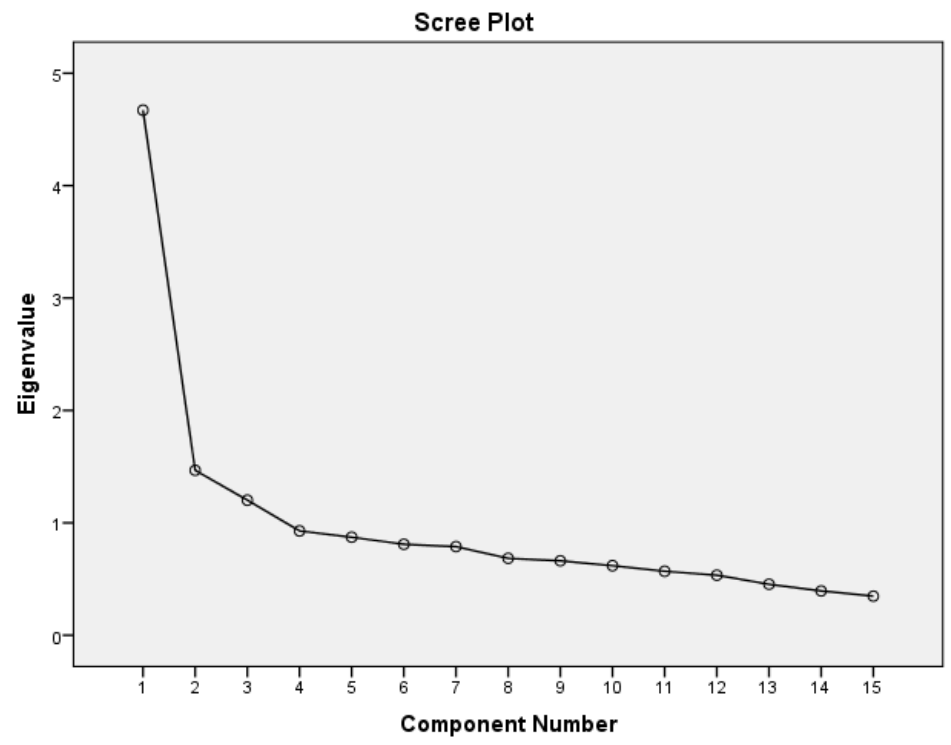

Figure 1. Line graph of the behavior patterns rating scale

Next, confirmatory factor analysis was conducted to evaluate the validity of the 3-factor scale that was obtained as the results of exploratory factor analysis of organization people pattern rating scale. The results of this from confirmatory factor analysis, are given in Figure 2 and Table 7.

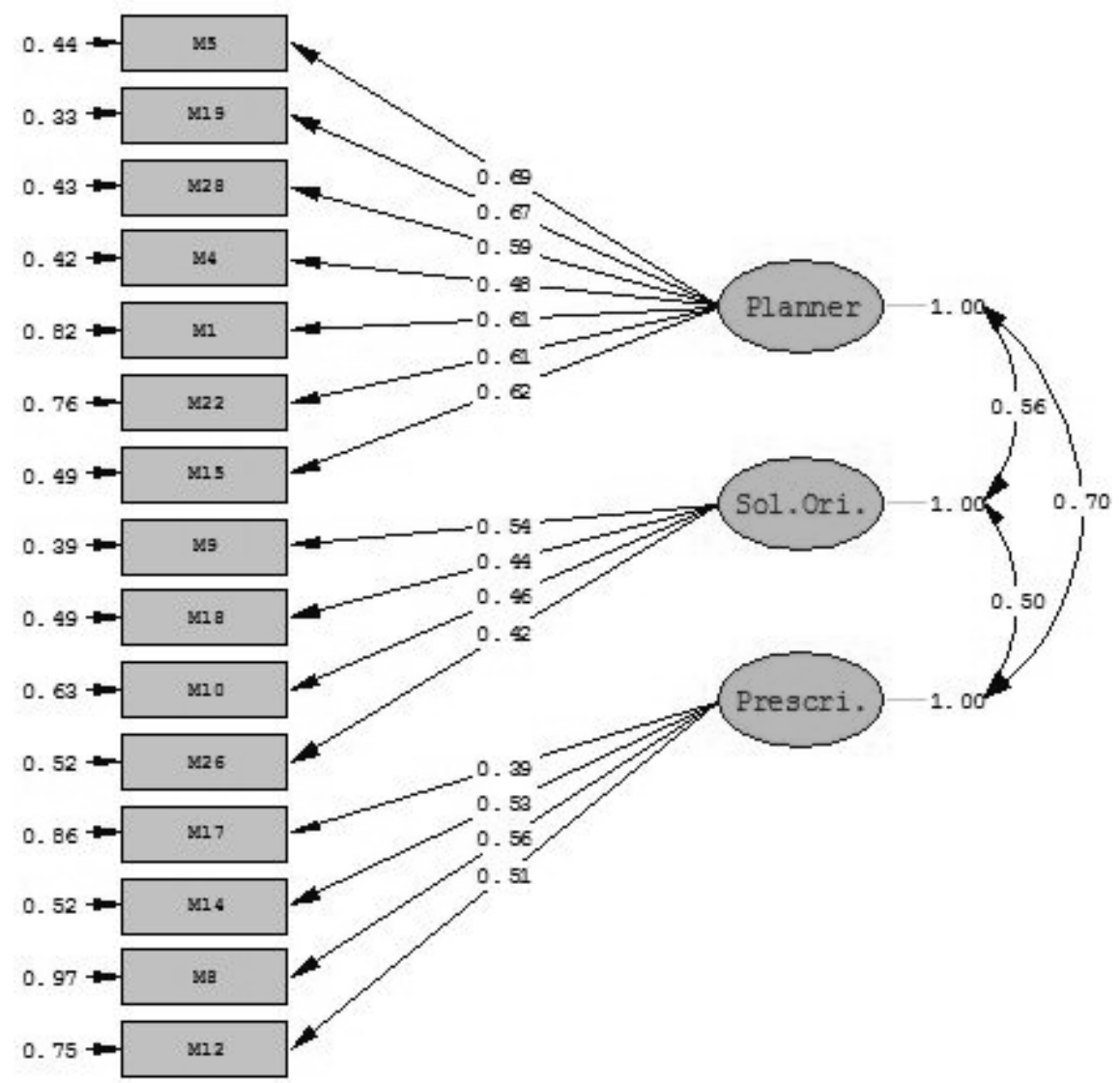

Figure 2. Confirmatory factor analysis path diagram 
As shown in Figure 2, factors are interrelated, and they have shown by double-headed arrow. The items has loaded strongly onto the single factor. Moreover, related correlation values are less than 1 . This result indicates that each item has a good representative. The correlation value is .56 between Planners and Solution-Oriented factors. The correlation value is .50 between Solution-Oriented and Prescriptive factors. In addition, the correlation value is .70 between Planners and Prescriptive factors. As shown in path diagram, there are one-way arrows between items and factors. This shows an one-way linear relationship. Moreover, the first factor has been most affected by Item 5 with .69 factor load. The second factor has been most affected by Item 9 with .54 factor load. The third and last fatcor has been most affected by Item 8 with .56 .

Table 7. The results of the confirmatory factor analysis

\begin{tabular}{lcccc}
\hline Index & $\begin{array}{c}\text { Perfect } \\
\text { Values }\end{array}$ & $\begin{array}{c}\text { Acceptable } \\
\text { Values }\end{array}$ & Findings & Results \\
\hline$\chi^{*}$ /dF & $0-3$ & $3-5$ & 3.40 & Acceptable \\
RMSEA & $.00-.05$ & $.05-.08$ & .063 & Acceptable \\
SRMI & $.00-.05$ & $.05-.10$ & .048 & Perfect \\
GFI & $.95-1.00$ & $.90-.95$ & .937 & Acceptable \\
AGFI & $.90-1.00$ & $.85-.90$ & .913 & Perfect \\
CFI & $.95-1.00$ & $.90-.95$ & .906 & Acceptable \\
\hline
\end{tabular}

Bollen (1989) advises that $\chi^{2} / d f$ value has to be between 0 and 5. Furthermore, if RMSEA (Root Mean Square Error of Approximation) value is less than .05 , then there is a perfect data compatibility. If the RMSEA value is between .05 and .08 , then there is an acceptable data compatibility. Moreover, it is prefered that SRMR (Standardized Root Mean Square Residual) value is less than .10. The models in which the SRMR value is above .10 are rejected because of the data compatibility issue (Browne \& Cudeck, 1993). In addition, it is advised that CFI (Comparative Fit Index) value should be .90 or higher (Hu \& Bentler, 1999). According to Brown (2006) and Kline (2005), there is no need to report the other indexes (Brown, 2006; Kline, 2005). Thus, in this study, our confirmatory factor analysis results confirmed exploratory factor analysis results. Moreover, the related Cronbach Alpha internal coefficient was found to be .830 for all the items in the scale (see Table 8). As a result of the analysis, the final scale, consisting of 15 items with five-points likert type and three factors was obtained (see Table 9).

Table 8. Reliability statistics

\begin{tabular}{ll}
\hline Cronbach's Alpha & N of Items \\
\hline .830 & 15 \\
\hline
\end{tabular}

Thus, it has been identified that behavior patterns rating scale in Table 8 of the organization people pattern can be confidently applied.

Table 9. The final scale which was translated to English by researchers

\begin{tabular}{lll}
\hline B.P. & No & Items \\
\hline Planner & 1 & I need to plan even for small things \\
Planner & 2 & I always keep my agenda ready \\
Sol.ori. & 3 & I never act without thinking about the results \\
Prescriptive & 4 & I am punctual and I want everyone to be punctual \\
\hline
\end{tabular}




\begin{tabular}{lll}
\hline Planner & 5 & I make plans for the future \\
Sol.ori. & 6 & I like thinking over a situation or an event and searching different solutions for them \\
Prescriptive & 7 & I like the rules, I want to be punished for breaking the rules \\
Planner & 8 & I prefer living planned and organized \\
Sol.ori & 9 & I can find unexpected solutions for different situations \\
Prescriptive & 10 & I cannot change my decisions easly \\
Planner & 11 & I live my life in line with a prepared plan \\
Planner & 12 & I behave planned considering the future \\
Prescriptive & 13 & I have specific rules and taboos \\
Planner & 14 & I care about tidiness of my works \\
Sol.ori. & 15 & I want to carry on things until I finish
\end{tabular}

No.: The item numbers of the final scale.

B.P.: The behavior patterns of the final scale with 15 items.

\section{Results and Discussion}

Woodsmall W. and Woodsmall M. (2003) argue that individuals in the organization people pattern have to be examined in two groups: "Structurist" and "Free spirits" behavior patterns. The individuals with structurist behavior patterns enjoy tidiness, being programmed and certainty in their lives. They tend to plan their works in particular orders and apply the plan they choose on time. Furthermore, the individuals with free spirits behavior patterns like sudden decisions, possibilities and improvisations. They prefer living as they want. We found that it is a contradictiory collect these two different typology under the same people patterns. In this regard, it is important to develop a new likert-type scale to evaluate to PSTs' behavior patterns in terms of the "Organization People Pattern".

A preliminary scale of 38 items with a five-points likert type was prepared by the authors reviewing the related iteratüre. After getting expert opinions, the number of items was reduced to 29. The preliminary scale of 29 items was given to 620 participants. The related Cronbach Alpha internal coefficient was found to be .830 for all the items in the scale, and it has been identified that behavior patterns rating scale of the organization people pattern can be confidently applied.

Statistical analysis have done for the individuals with behavior patterns of the organization people pattern, and as a result of the factor analysis, it has been observed that their typologicals were gathered around "Planner", "Solution-oriented" and "Prescriptive" behaviors. The items of free spirits behavior patterns were excluded in the study because they decreased reliabilitiy. Confirmatory factor analysis was conducted to evaluate the validity of the 3-factor scale that was obtained as the results of exploratory factor analysis of organization people pattern rating scale and the data were approved. Therefore, our result contradicts with Woodsmall W. and Woodsmall M. (2003)'s theoretical analysis. Woodsmall W. and Woodsmall M.'s idea related to behavior patterns of the organization people pattern is a theoric analysis. However, we observed that the results from their theoretical analysis and our scientific data contradict. Thus, we claim that the individuals with behavior patterns of the organization people pattern have "Planner", "Solution-oriented" and "Prescriptive" typologicals. The individuals in the organization people pattern have been examined by Woodsmall W. and Woodsmall M. (2003) in two groups: structurist and free spirits behavior patterns. However, we observed that with the use of new scale three such gruops: planner, solution-oriented and prescriptive, emerge. Thus, we provided a new idea related to behavior patterns of the organization people pattern. In our following study, we will examine whether teachers and preservice teachers have "Planner", "Solution-oriented" and "Prescriptive" behavior patterns of the organization people pattern or not. In addition, using the scale, we will evaluate teachers' and preservice teachers' behaviors according to the some demographics such as gender, educational status and income. 


\section{Acknowledgements}

The authors would like to express their gratitude to the referees for their valuable comments and suggestions. The authors declare that there is no conflict of interests regarding the publication of this paper. A part of this study was presented in 1st International Academic Research Congress, Antalya, Turkey, 2016. Moreover, the work was supported by Ahi Evran University Scientific Research Projects Coordination Unit. Project Number: EGT.A3.16.011.

\section{References}

Bollen, K. A. (1989). A new incremental fit index for general structural equation models. Sociological Methods and Research, 17, 303-316. http://dx.doi.org/10.1177/0049124189017003004

Brown, T. A. (2006). Confirmatory factor analysis for applied research. New York, NY: The Guilford Press.

Browne, M., \& Cudeck, R. (1993). Alternative ways of testing structural equation models. Testing Structural Equation Models. London: Sage.

Bütüner, Ö. S., \& Gür, H. (2007). V diyagramına yönelik bir tutum ölçeğinin geliştirilme çalışması. Milli Eğitim Dergisi, 176, 72-85.

Büyüköztürk, Ş. (2007). Sosyal bilimler için veri analizi el kitabı. Pegem A Yayıncılık, Ankara.

Büyüköztürk, Ş., Çakmak, E. K., Akgün, Ö. E., Karadeniz, Ş., \& Demirel, F. (2009). Bilimsel Araştırma Yöntemleri. Pegem Akademi, Ankara.

Domović, V., Vidović Vlasta, V., \& Bouillet, D. (2016). Student teachers' beliefs about the teacher's role in inclusive education. European Journal of Special Needs Education, 31, 1-16. http://dx.doi.org/10.1080/08856257.2016.1194571

Erden, M. (1998). Öğretmenlik Meslĕgine Giriş. Alkım Yayınları, İstanbul.

Greca, M. A., Dandes, K. S., Wick, P., Shaw, \& Kand Stone, L. W. (1998). Development of the social anxiety scale for children: Reliability and concurrent validity. Journal of Clinical Child Psychoogy, 17, 84-91. http://dx.doi.org/10.1207/s15374424jccp1701_11

Hu, L. T., \& Bentler, P. M. (1999). Cutoff criteria for fit indexes in covariance structure analysis: Conventional criteria versus new alternatives. Structural Equation Modeling: A Multidisciplinary Journal, 6(1), 1-55. http://dx.doi.org/10.1080/10705519909540118

Huang, H. M. (2005). Web performance scale. Information and Management, 42, $841-852$. http://dx.doi.org/10.1016/j.im.2004.06.003

Hwang, C., \& Henry, L. (1990). Development and validation of the mathematics anxiety scale for children. Measurement and Evaluation in Counseling and Development, 23(3), 121-127.

Kaiser, F. (1970). A second generation little jiffy. Psychometrika, 35, 401-415. http://dx.doi.org/10.1007/BF02291817

Kline, P. (1994). An Easy Guide To Factor Analysis. New York, NY: Routledge.

Kline, R. B. (2005). Principles and practice of structural equation modeling. New York, NY: Guilford Press.

O’Connor, J., \& Seymour, J. (2011). Introducing NLP: Psychological skills for understanding and influencing people. Conari Press, San Francisco, USA.

Rennie, K. M. (1997). Exploratory and Confirmatory Rotation Strategies in Exploratory Factor Analysis. Paper presented at the Annual Meeting of the Southwest Educational Research Association, Austin, USA.

Sisman, M., \& Acat, B. (2003). A study of school experiences practices and its effect on the perception of teaching profession. Firat University Journal of Social Science, 13, 235-250.

Srinivasan, S., \& Ambedkar, V. (2015). Job satisfaction towards teaching profession among the higher secondary school teachers. IJAR, 1(3), 66-68.

Staddon, J. E. (2016). Adaptive behavior and learning. Cambridge University Press. http://dx.doi.org/10.1017/cbo9781139998369

Stapleton, C. D. (1997, January). Basic concepts and procedures of confirmatory factor analysis. Paper presented at the Annual Meeting of The Southwest Educational Research, Austin, TX. 
Stevens, J. (1996). Appied multivariate statistics for the social science (3rd ed.). Lawrence Erlbaum Associates, Mahwah, NJ.

Tavşancıl, E. (2014). Tutumların ölçülmesi ve spss ile veri analizi. Nobel Yayıncılık, Ankara.

Tsai, L. S., \& Chai, K. S. (2005). Developing and validating a nursing website evaluation questionnaire. Methodological Issues in Nursing Research, 49(4), 413-416. http://dx.doi.org/10.1111/j.1365-2648.2004.03304.x

Turkish Ministry of Education. (1973). Basic Law of the National Education.

Woodsmall, M., \& Woodsmall, W. (1998). People pattern power: The nine keys to business success. International research institute for human typological studies.

Yavuz, S. (2005). Developing a technology attitude scale for pre-service chemistry teachers. The Turkish Online Journal of Educational Technology, 4(1), 17-25.

Yazıcı, K. (2006). Değerler eğitimine genel bir bakış. Türklük bilimi Araştırmaları, 19, 499-522.

Yaakub, N. F. (1990). Personality Patterns of Teacher Trainees from a Malaysian Training College. Pertanika, 13, 139-144.

\section{Appendix}

The final scale in which the original language was Turkish

\begin{tabular}{|c|c|c|}
\hline Dav.Örün. & No & Maddeler \\
\hline$\underline{\text { Planlamac1 }}$ & 1 & Küçük işlerim için bile plan yapma gereği duyarım. \\
\hline$\underline{\text { Planlamac1 }}$ & 2 & Yapılacak işler listesini her zaman hazır tutarım \\
\hline Çözümcü & 3 & Sonuçlarını düşünmeden asla bir şey yapmam \\
\hline Kuralcı & 4 & Dakiğim ve çevremdekilerin de öyle olmasını isterim \\
\hline Planlamacı & 5 & Gelecekle ilgili planlar yaparım \\
\hline Çözümcü & 6 & Bir olay, durumla ilgili düşünmekten ve farklı çözüm yolları aramaktan hoşlanırım \\
\hline Kuralcı & 7 & Kurallardan yanayım, kurallara uymayanların cezalandırılmasını isterim \\
\hline$\underline{\text { Planlamac1 }}$ & 8 & Düzenli ve planlı yaşamayı tercih ederim \\
\hline Çözümcü & 9 & Farklı olaylar karşısında beklenmedik çözümler üretebilirim \\
\hline Kuralcı & 10 & Verdiğim kararları kolay kolay değiştiremem \\
\hline$\underline{\text { Planlamaci }}$ & 11 & Hayatımı önceden hazırladığım bir plan doğrultusunda yaşarım \\
\hline Planlamacı & 12 & Geleceği düşünerek planlı hareket ederim \\
\hline Kuralcı & 13 & Belirli kurallarım ve tabularım vardır \\
\hline Planlamacı & 14 & Yaptığım işlerin düzenli olmasına özen gösteririm \\
\hline С̧özümcü & 15 & Her şeyi sonuna kadar götürmek isterim \\
\hline
\end{tabular}

No.: 15 maddelik nihai ölçeğin madde numaraları.

D.Ö.: 15 maddelik nihai ölçeğin davranış örüntüleri. 


\section{Copyrights}

Copyright for this article is retained by the author(s), with first publication rights granted to the journal.

This is an open-access article distributed under the terms and conditions of the Creative Commons Attribution license (http://creativecommons.org/licenses/by/4.0/). 